\title{
Consumer Attitude and Perception towards Green Products
}

\author{
SuboohYusuf ${ }^{1}$, Zeenat Fatima ${ }^{2}$
}

\section{ABSTRACT:}

"Green Marketing" refers to holistic marketing concept wherein the production, marketing consumption and disposal of products and services happen in a manner that is less detrimental to the environment with growing awareness about the implications of global warming, nonbiodegradable solid waste, harmful impact of pollutants etc. Both marketers and consumers are becoming increasingly sensitive to the need for switch in to green products and services (Mudhassir, 2010). .Green consumers can be defined as one:- "Who is mindful of environment related issues and obligations, and is supportive of environmental causes to the extent of switching allegiance from one product or supplier to another even if it entails higher cost". Thus the purpose of the research was to explore the concept of green marketing, or green products in relation to consumer behavior. Samples were selected through random sampling. 70 college going students of Aligarh Muslim University participated in the research. Green consumer value scale by Haws et al (2010) and sustainability endorsement scale by William A.McConochie were used to measure the consumer behaviour. For statistical analysis Pearson correlation was used.

Keywords: Green Marketing, Green Products, Green Consumer, detrimental, Consumer Behaviour

At present, the world is facing an environmental crisis, which influences our behavior to protect our planet. The detrimental consumption behavior of the human being is a cause of the environmental degradation.(Islam \& Zabin,2003). That is why the consumer behaviour and attitude transit towards the green product or green marketing concept.

There are two ways of defining the word Green Marketing. The first way is marketing and the second way is a Marketing Philosophy. As far as marketing is concerned, it is defined as a marketing of industrial products and services. It especially emphasis in marketing of a specialized kind of product which is known as Green Product(it includes goods such as fuel efficient cars or recycled products as well as green ideas such as save oil or conserve natural habitat).

\footnotetext{
${ }^{1}$ M.Phil, Department of Psychology, Aligarh Muslim University, Aligarh, U.P., India

${ }^{2}$ Research Scholar, Department of Commerce, Aligarh Muslim University, Aligarh, U.P., India

(C) 2015 I S Yusuf, Z Fatima; licensee IJIP. This is an Open Access Research distributed under the terms of the Creative Commons Attribution License (http://creativecommons.org/licenses/by/2.0), which permits unrestricted use, distribution, and reproduction in any Medium, provided the original work is properly cited.
} 


\section{Consumer Attitude and Perception towards Green Products}

Hence, the products those are manufactured through green technology and that caused no environmental hazards are called green products. Promotion of green technology and green products is necessary for conservation of natural resources and sustainable development. As a philosophy, green marketing runs side by side with the societal marketing concept and endorse the view that satisfying the consumer needs is not enough rather marketing should considered the environment of the society as a whole. Therefore, it is a part of corporate social responsibility.

Green marketing emerges from societal marketing.(Kotler, 1999). "Green Marketing" refers to holistic marketing concept wherein the production, marketing, consumption and disposal of products and services happen in a manner that is less detrimental to the environment with growing awareness about the implications of global warming, non-biodegradable solid waste, harmful impact of pollutants, etc. Both marketers and consumers are becoming increasingly sensitive to the need for a switch into green products and services. . (Mudhassir, 2010).

The produce goods and services are, ultimately, used by the consumer for satisfying their needs and wants. The green marketing concept is incomplete until and unless consumers get a higher degree of satisfactions and benefits from the sacrificing resource in acquiring the green products. It is behaviour and perception of a consumer toward green product through which the success or failure can be evaluated. According to Nayan R. Sinha, A green consumer is one who is very concerned about the environment and, therefore, only purchases products that are environmentally-friendly or eco-friendly. Products with little or no packaging, products made from natural ingredients and products that are made without causing pollution are all examples of eco-friendly products. The green consumer would be the type to drive a hybrid vehicle, buy products made with hemp or those made from recycled materials.

Dodds, John (2006) observed that harnessing the consumer's power gives a positive effect in changing the environment. The so-called "green consumer" movement in US and other countries help them to reach the critical mass and all this directly affect the shoppers' minds effectively. This study helps us in knowing that how consumers transform to green consumers.

Hans, Jim (2007) noted that green marketers taken the advantage of confusion prevailing in the market place among the consumers' minds. They purposely make false or exaggerate 'green claims'. Following the same logic, it becomes possible to argue that green marketing leads to fantasy in the world where consumers need eco-friendly environment.

D'Souza et al. (2007) stated that demographics tend to play an important role in regards both the interest of green product and green certification.

Green Trade \& Development (2008) discussed that consumers is said to be changing their attitude and perception and profess a strong willingness in favour of eco-friendly environment. This concept helps us in realizing a fact that how much a consumer is conscious about their environment. 
Cervellon et al. (2010) and Yiridoe at el. (2005)demonstrated that the demand of green products is increasing day by day all over the world and as such there is concern for understanding how green is a green product. One of the most important restrains to the development of green products is the lack of consumer trust and the lack of information. This shows us that consumer's attitude and perception playan important role in promoting the green product.

Since 1990, there have been myriad of research are done on analysing the consumer attitude towards green products at academics as well as industrial level. Most of the studies are done in developing countries and captures that population, whose standard of living, taste and preference are totally different from us, but such studies, however, is not valid in the context of developing countries where most of the people are on the middle level income group.

This exploratory research discussed the concept of green marketing and it connection with consumer attitude and perception. The data collection is based on a field survey of college or university going youths.

$\mathrm{H}_{1}$ - Consumer attitude and perception are positively related to each other.

$\mathrm{H}_{2}$ - People are concerned about a green product.

\section{RESEARCH METHODOLOGY}

\section{Sampling and data collection-}

The random sampling method was adopted for gathering samples of 70 students from Aligarh Muslim University. Scales used in present study was Green Value Scale by Haws et al (2010) and Sustainability Endorsement Scale by William A. McConochie which were five-point scale.

\section{Statistical tool used-}

The collected data had been analysed by using mean rating scale, correlation, pie chart and bar diagram. 
ANALYSIS AND INTERPRETATION-

Descriptive Statistics

1) Below is the table showing mean value and standard deviation of sustainability endorsement and consumer value.

TABLE 1

\begin{tabular}{|l|l|l|l|}
\hline & Mean & Standard deviation & $\mathrm{N}$ \\
\hline $\begin{array}{l}\text { Sustainability } \\
\text { endorsement scale }\end{array}$ & 49.9125 & 4.48681 & 80 \\
Consumer value scale & 1.6871 & 11.32064 & 80 \\
\hline
\end{tabular}

The above table shows the mean and standard deviation of sustainability endorsement scale and green consumer value scale. The mean of sustainability endorsement and consumer value scale was found to be 49.912 and 1.6871 respectively.

2) Correlation computed by using Pearson correlation between consumer attitude and perception towards green marketing.

TABLE 2

\begin{tabular}{|l|l|l|l|}
\hline & & Ses & Gcvs \\
\hline $\begin{array}{l}\text { Sustainability } \\
\text { endorsement scale }\end{array}$ & Pearson Correlation & 1 & .137 \\
& $\begin{array}{l}\text { Sig. (2-tailed) } \\
\text { Sum of Squares and }\end{array}$ & 1.590 & .225 \\
& Cross-products & 20.131 & 550.988 \\
& Covariance & 80 & 6.975 \\
& $\mathrm{~N}$ & 80 \\
\hline Green consumer value & Pearson Correlation & .137 & 1 \\
scale & Sig. (2-tailed) & .225 & \\
& Sum of Squares and & 550.988 & 1.012 \\
& Cross-products & 6.975 & 128.157 \\
& Covariance & 80 & 80 \\
& N & & \\
\hline
\end{tabular}

From above table it can be inferred that coefficient correlation was found to be 1.590 which means there is a positive relation between consumer attitude and perception. When there is increase in attitude there will be increase in perception. Selvakumar \& Ramesh Pandi (2011) indicated that Green Marketing is not all about manufacturing green products and services but encompassing all those marketing activities that are needed to develop and sustain consumerse eco-friendly attitudes and behaviours in a way that helps in creating minimal detrimental impact on the environment 


\section{3) People heard of "Environment Friendly or Green Marketing" products/practices}

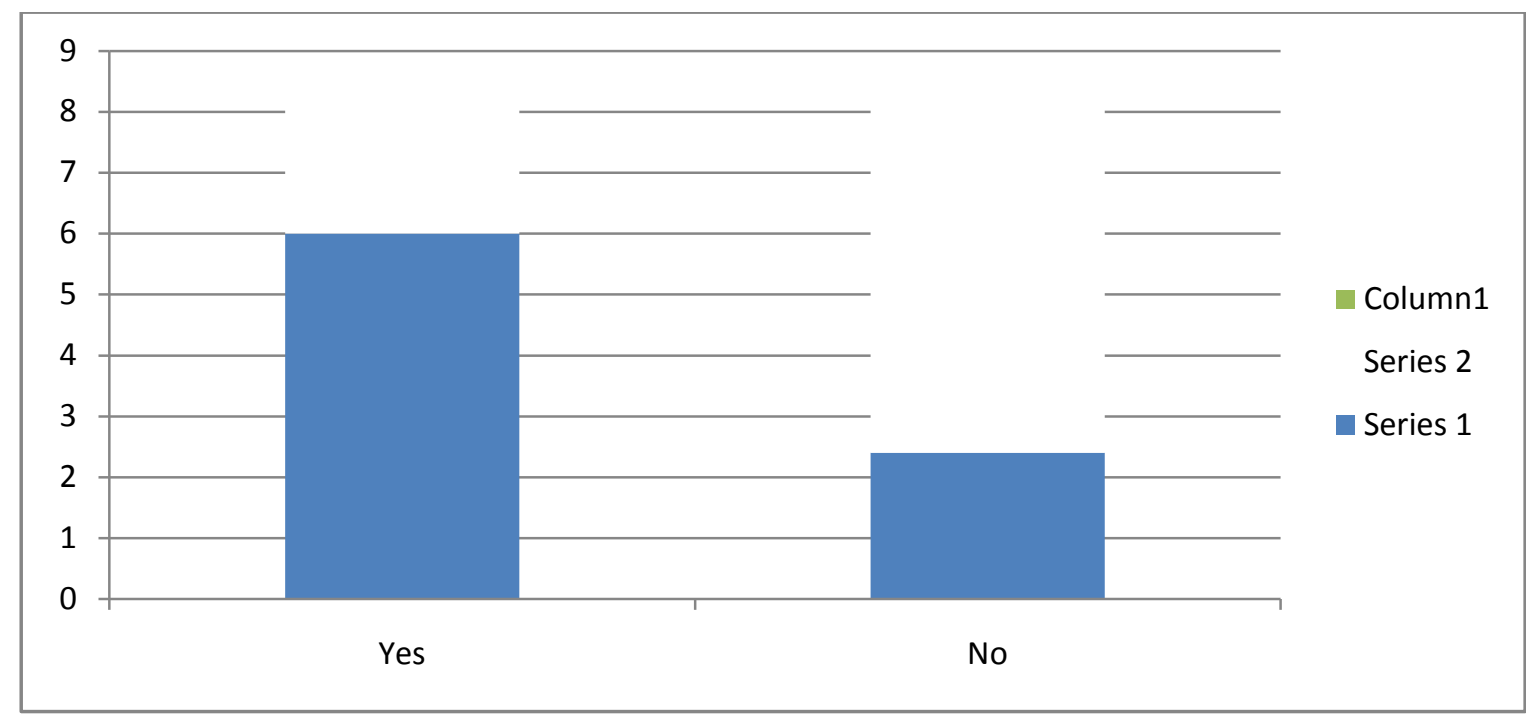

\section{TABLE 3}

From Above bar diagram it can be seen that people are aware of green products. About $60 \%$ of the respondents were aware of the green products

4) Sources from where people get information about Green Marketing

TABLE 4

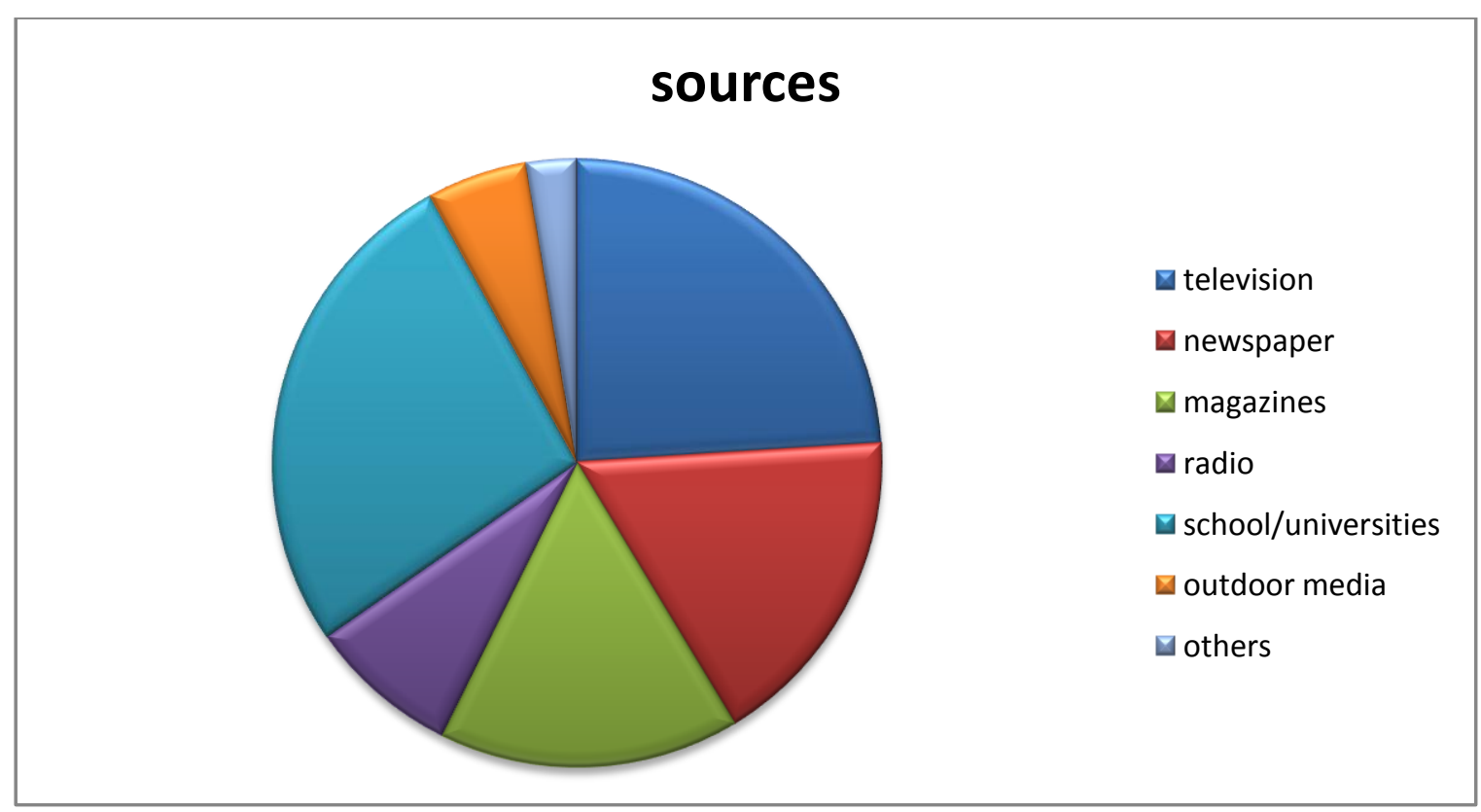

Above pie chart states that most of the information about green marketing people get from school/universities then newspaper and least from outdoor media and others. Robert Dahlstrom 
(2011) examined that Green Marketing has positive influences on multiple participants in the economy.

\section{5) Rate the components of advertisements on a scale of 1 to 5}

\section{TABLE 5}

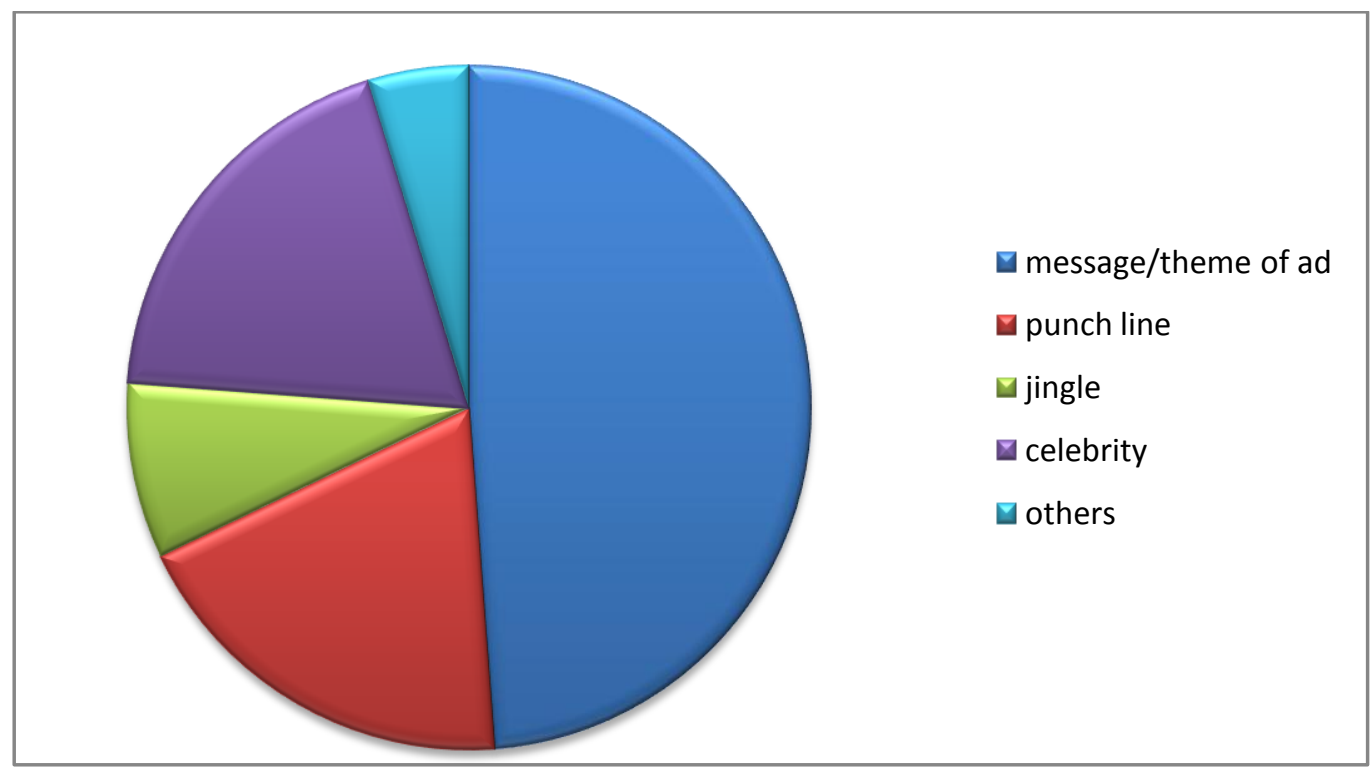

Above pie chart indicates that in the advertisement the most important component is a message, then punch line and least important is a jingle and others. Mamatha (2010) found that brand, price, store, design/features and advertisement were the most crucial five factors in revealing the quality of the products.

\section{CONCLUSION}

It has been observed from the analysis that large population thinks that eco-friendly products are good for the environment and are also healthy for them. Eco-friendly products are good quality and the performances of these are better than the conventional products.

These products are easily available in the market with reasonable prices. Ranjith\&ElaGoyal (2011) highlighted that highest brand memory, brand recall, brand that connects with the people, pricing, overall satisfaction in the long life of the product and communication programs designed by the company are the parameters that influence the consumer perception.

The Attitude of the people towards the eco-friendly products is remarkable. They believe that the eco-friendly products provided them a good packaging design. Andrew S.Winston (2010) summarized in their study that Companies and countries must deal with current and longer-term environmental issues while simultaneously working on 


\section{Consumer Attitude and Perception towards Green Products}

current economic challenges. Robert Dahlstrom (2011) examined that Green Marketing has positive influences on multiple participants in the economy. The environment, developing economies, consumers, corporate strategy, the product, production processes, and supply chain benefit from green marketing.Roger A Kerin et al (2007), Green Marketing takes many forms. It comes from product development opportunities that emanate both from consumer research and its "Pollution Prevention Pays" program. This program solicits employee suggestions on how to reduce pollution and recycle materials.

\section{REFERENCES}

1. Chang, C. (2011). Feeling ambivalent about going green - Implication For Green Advertising Processing. Journal of Advertising, 40(4), 19-31.

2. Cherian, J. et al. (2012). Green Marketing: A Study of Consumers' Attitude towards Environment Friendly Products. Asian Social Science, Vol. 8 Issue 12, p117

3. Deli-G., Gillpatrick Z., T., Marusic, M., Pantelic, D. \&Kuruvilla, S.J (2011). Hedonic and Functional Shopping Values and Everyday Product Purchase: Findings from the Indian Study. International Journal of Business Insights \&Transformation, 4(1), 65-70.

4. Islam, S. \&ZabinI. (2003). Consumer's attitude towards purchasing of green food. European journal of business and management, Vol. 5, p.no.9, 2222-2839.

5. Kaman, L. (2008). Opportunities for green marketing: young consumers. Marketing Intelligence \& Planning, 26, 573-586.

6. Morel, M. \&Kwakye, F. (2012). Green marketing: Consumers' Attitudes towards Ecofriendly Products and Purchase Intention in the Fast Moving Consumer Goods (FMCG) sector.

7. Mudhassir, (2010). Green Marketing Examples. StudyMode.com. Retrieved 03, 2010, from http://www.studymode.com/essays/Green-Marketing-Examples-302385.html

8. Saxena, R. P. \&Khandelwal, P. K. 2008, 'Consumer attitude towards green marketing: an exploratory study', European Conference for Academic Disciplines,

9. Sinha, Nayan R. Green Marketing - New Opportunities and Challenges. SilionIndianBlog Retrieved://blogs.siliconindia.com/nayan/Green_Marketing_New_Oppertunities_and_C hallenges-bid-uQo5nC9M35974297.html

10. Stern P. C. (2000), Psychology and the Science of Human-Environment Interactions, American Psychologist, 55(5), 523-530.

11. Tan Booi Chen and Lau Teck Chai (2010). "Attitude towards the Environment and Green marketing"

12. Www.greenmarketing.net/stratergic.html.

13. www.epa.qld.gov.au/sustainable_industries.

14. www.greenpeace.org/international. 